\title{
Evaluation of long-term operation of combined system for heating the building and preparation of domestic hot water
}

\author{
Dawid Taler ${ }^{1, *}$, Rafat Pitry ${ }^{1}$, and Jan Taler ${ }^{1}$ \\ ${ }^{1}$ Cracow University of Technology, Faculty of Environmental Engineering , Warszawska 24, \\ 30-001 Krakow, Poland \\ ${ }^{2}$ Thermo-Instal Company, Bałandy 4D/8, 32-600 Oświęcim, Poland
}

\begin{abstract}
The paper presents, the results of research on the operation and energy efficiency of a $186 \mathrm{~kW}$ gas-fired condensing boiler operating in a hybrid heat source system. The boiler co-operates with an $81.1 \mathrm{~kW}$ (electric) brine-to-water compressor heat pump, a $27.4 \mathrm{~kW}$ air-to-water heat pump and 6 flat solar collectors. A local, built-in, hybrid heat source is located in a public building and is intended to satisfy the building needs. The study was conducted over a period of 1 year - from 1 September 2014 to 31 August 2015. The gas-fired boiler operates in the heating buffer system all year round. The boiler performance is characterized both in the winter and in the summer season, in terms of the amount of heat produced and the heating power. The calculations results of the heat generation efficiency obtained in the measuring period are also presented
\end{abstract}

\section{Introduction}

In recent years, fossil fuel shortage and environmental pollution have resulted in the rapid use of renewable energy sources. Hybrid systems of supplying residential buildings with electricity, heat and domestic hot water that combine photovoltaic cells, solar collectors, ground and air heat pumps and gas boilers quickly develop. Combined heating, cooling and power systems including domestic hot water preparation have been the subject of numerous publications in recent years. The feasibility and affordability of hybrid photovoltaic-thermal (PV-T) collectors coupled with thermal or electrical solar heating and cooling systems (absorption chillers or heat pumps) were studied in [1], also using thermal energy storage. The proposed systems were analyzed in 4-5 person households with a $100 \mathrm{~m}^{2}$ floor area and $50 \mathrm{~m}^{2}$ rooftop area suitable for installation of solar collectors. Ten selected locations with different climatic conditions in Europe were studied. A least-cost investment methodology that optimizes the hybrid power-residential heating system, including thermal energy storage, was developed in [2]. Different configurations were considered: gas boiler-electric resistance heater, heat pump-gas boiler, and heat pump-electric resistance heater. The hybrid ground heat exchangers of ground-coupled heat pump systems using vertical, as well as horizontal heat exchangers, were studied in [3]. The optimum load ratio of horizontal to vertical ground

* Corresponding author: dtaler@pk.edu.pl 
heat exchangers was found. The performance of a heat pump with hybrid heat source including solar and air energy using different refrigerants was simulated in [4]. Based on a lumped parameter model of the heat pump, the characteristics of the heat pump as the power consumption and coefficient of performance (COP) were established for three refrigerants $\mathrm{R} 22, \mathrm{R} 134 \mathrm{a}, \mathrm{R} 744$, and $\mathrm{CO}_{2}$. There are no significant differences in the performance of the heat pump used three different refrigerants. The heat pump with $\mathrm{CO}_{2}$ as the working fluid has a low COP, but it has a good low-temperature performance. The efficiency of new power sources (co-generation, tri-generation systems, fuel cells, photovoltaic systems) can be enhanced using heat pipe heat exchangers and solid sorption heat pumps [5]. In this paper, the results of experimental investigations of a hybrid heating and domestic hot water preparation system in a public building are presented. The wide variety of micro and mini heat sources currently offered by manufacturers makes it possible to design solutions not only with a single energy-generating device but also with more complex hybrid heat source systems including two or even more heat generators. Due to technical requirements, e.g., high supply temperature, or economic limitations, e.g., low cost of purchase, renewable heat sources, such as heat pumps or solar collectors, often need a traditional heat generator such as a gas-fired boiler. Each stage of development of this type of solutions - investment, design, construction or operation - is highly complex, and the comprehensive approach to the problem should not be based on a one-off, fragmentary and out-of-context analysis of the device, but on a comprehensive analysis of all aspects of the hybrid solution operation. The considerations presented herein are limited to the gas-fired boiler assessment and significance in a hybrid heat source in relation to the amount of generated thermal energy, the share of thermal output, working time and heat generation efficiency. Previous analyses of hybrid source systems for heating and preparing domestic hot water were carried out using various computer simulation programs. In this paper, the actual experimental results of one-year operation of hybrid source installations were presented.

\section{Characteristics of investigated hybrid heat source}

The aim of the analysis is a gas-fired boiler operating in a local hybrid heat source system located in the modern building of the Headquarters of the State Fire Service in Oświęcim, Matopolska province (voivodeship). The building and the installations were put in use in September 2011. The headquarters building is supplied with thermal energy by a local hybrid heat source, the center of which is a buffer tank. The hydronic system flowchart is shown in Fig. 1. The heat source includes:

- KG: a floor-standing Vitocrossal 200 CM2 186 kW gas-fired condensing boiler with a compact modulating MatriX burner,

- PC1: a Thermalia $9081.1 \mathrm{~kW}$ (B0W35), $109.3 \mathrm{~kW}$ (W10W35) brine-to-water compression (ground source) heat pump made by the Hoval company, with a lower heat source in the form of 18-meter deep vertical brine probes,

- PC2: a Belaria $2727.4 \mathrm{~kW}$ (A2W35) air-to-water compression heat pump made by the Hoval company,

- KS: Vitosol 100 SV1 flat solar collectors made by the Viessmann company, with thegross surface area of $6 \times 2.51 \mathrm{~m} 2$.

The heat source operates for the heating, ventilation and domestic hot water preparation. Due to the different temperature characteristics, the heat-receiving systems are divided into two groups. The first group comprises low-temperature heating circuits $\left(60 / 45^{\circ} \mathrm{C}\right)$ with lowtemperature parameters (NP) 1-3 (marked in Fig. 1 as R1). The total power of the receivers is $129.2 \mathrm{~kW}$. The second group includes heating circuits with numbers 4-7 and domestic hot water installation. This group is characterized by high-temperature parameters (WP) (marked in Fig. 1 as R2), with the total power of $231.7 \mathrm{~kW}$ and a design temperature of $80 / 60^{\circ} \mathrm{C}$. 


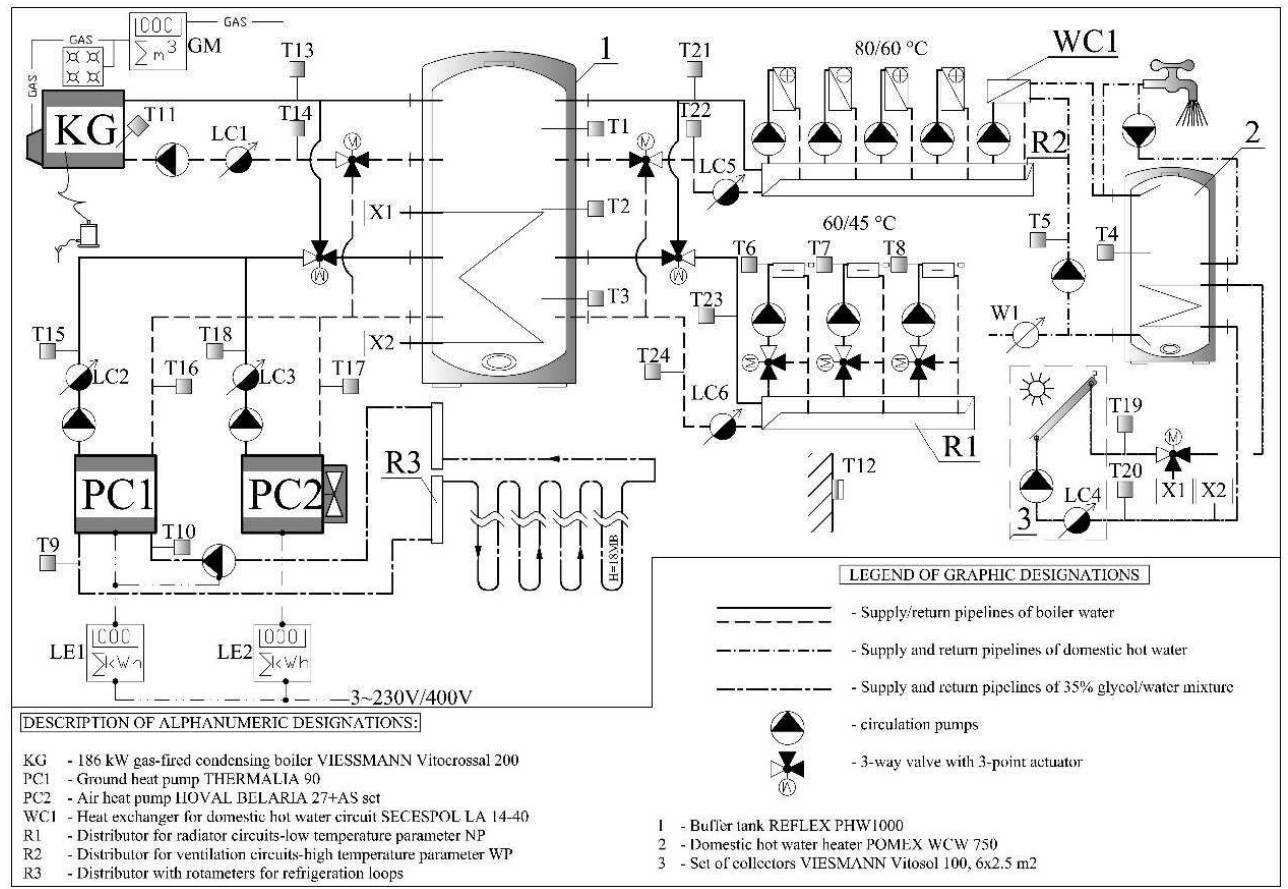

Fig. 1. Technological flowchart of the hybrid heat source including the measuring elements. Basic marking adopted in the measuring system: LC1 $\div$ LC6 - heat meters, LE1, LE2 - electricity meters, $\mathrm{W} 1$ - domestic hot water meter, GM - bellows gas meter, T1 $\div \mathrm{T} 22$ - temperature transducers, the other markings are in the figure

The building of the Headquarters of the Local Government Fire Station is located in climatic zone III. The facility is composed of three units performing different functions. The building total cubic volume is $18432.15 \mathrm{~m}^{3}$. The research was conducted from 1 September 2014 to 31 August 2015.

\section{Test facility and measurements results}

A new system of control, measurement, and recording of the entire heat source necessary operating parameters was designed for the needs of the research works. The measuring system flowchart is presented in Fig. 1. The technological system was equipped with water flow and heat meters, meters of the electric power network parameters and a masterPLCtype [6] data acquisition system made by the Altel company. Combustion analysis was performed to assess the gas-fired boiler combustion quality. The technological system and the measuring system are controlled by a master PLC controller.

\section{Thermal energy production}

During the measuring year (Fig. 2) the most significant amounts of thermal energy were generated by gas-fired boiler $\mathrm{KG}-470.1 \mathrm{GJ} /$ year $(51.11 \%)$, brine-to-water heat pump PC1 - 395.7 GJ/year (43.02\%), air-to-water heat pump PC2 - $35.8 \mathrm{GJ} /$ year (3.89\%), and solar collectors KS $-18.2 \mathrm{GJ} /$ year $(1.98 \%)$. The amount of thermal energy produced in the heating season is many times larger compared to the heat generated in the summer season: $878.2 \mathrm{GJ}$ and 41.6 GJ, respectively. For this reason, the percentage share of energy generated by individual devices in the heating season (Fig. 3) is close to the annual value. In the summer 
season, the opposite is the case (Fig. 4) - the most significant amounts of thermal energy were generated by heat pump PC2 $-25.8 \mathrm{GJ} /$ summer season $(62.02 \%)$, solar collectors $\mathrm{KS}$ - $10.8 \mathrm{GJ} /$ summer season $(25.96 \%)$ and gas-fired boiler $\mathrm{KG}$ - $5.0 \mathrm{GJ} /$ summer season $(12.02 \%)$. During the summer, heat pump PC1 did not operate.
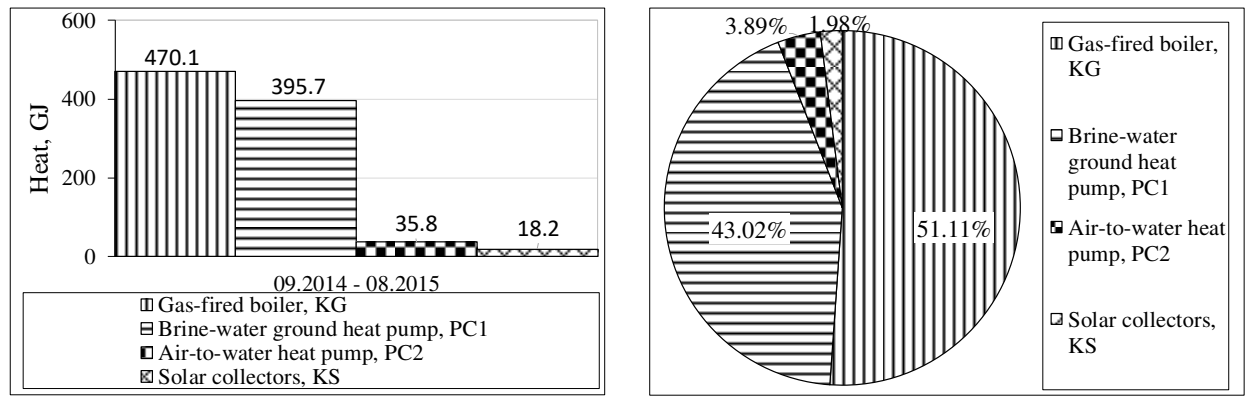

Fig. 2. Results of measurements of thermal energy production by individual generating devices in theentire measuring year by amount and percentage
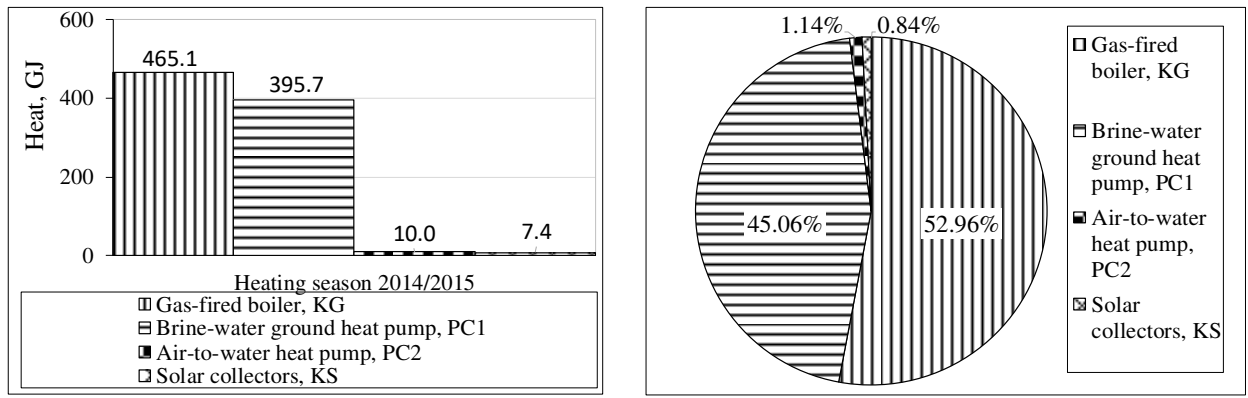

Fig. 3. Results of measurements of thermal energy production by individual generating devices in the heating season by amount and percentage
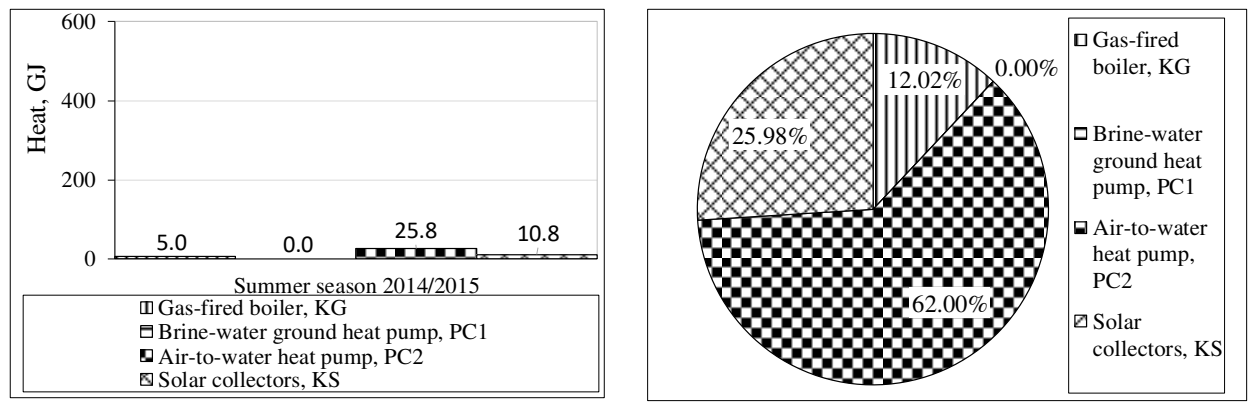

Fig. 4. Results of measurements of thermal energy production by individual generating devicesin the summer season by amount and percentage

\section{Planning of diagnostic experiments}

During the heating season, the gas-fired boiler operated with an average thermal power of $119.1 \mathrm{~kW}$ with a standard deviation of $42.6 \mathrm{~kW}$. For the summer season, the thermal power and the standard deviation values were $95.3 \mathrm{~kW}$ and $47.3 \mathrm{~kW}$, respectively, which in the 
whole year under consideration gives the boiler operation with the average thermal power of $118.8 \mathrm{~kW}$ with a standard deviation of $42.8 \mathrm{~kW}$. The typical values for the winter (heating) and the summer seasons and the entire measuring year are $157.0 \mathrm{~kW}, 131.0 \mathrm{~kW}$, and $157.0 \mathrm{~kW}$, respectively. The thermal power typical values are close to the gas-fired boiler maximum value of $186 \mathrm{~kW}$. The charts are illustrating monthly thermal power values (Fig. 5 and Fig. 6) point to the gas-fired boiler cyclic operation ensuring an appropriate level of temperature in the buffer tank. Thermal power is supplied to the buffer tank in a wide range from $0 \mathrm{~kW}$ to $375 \mathrm{~kW}$, which momentarily exceeds the boiler maximum power. This is the effect of the system being cooled down and the occurrence of a difference between the water temperature at the outlet and the inlet of the boiler higher than design temperature difference equal to $20 \mathrm{~K}$. Table 1 presents the monthly and annual characteristics of the gas-fired boiler output.

Table 1. Results of measurements of the gas-fired boiler (KG) thermal output

\begin{tabular}{|c|c|c|c|c|c|}
\hline $\begin{array}{c}\text { Period of } \\
\text { analysis }\end{array}$ & $\begin{array}{c}\text { Maximum } \\
\text { output, } \mathrm{kW}\end{array}$ & $\begin{array}{c}\text { Mean } \\
\text { output, } \mathrm{kW}\end{array}$ & $\begin{array}{c}\text { Period } \\
\text { of analysis }\end{array}$ & $\begin{array}{c}\text { Maximum } \\
\text { output, } \mathrm{kW}\end{array}$ & $\begin{array}{c}\text { Mean } \\
\text { output, } \mathrm{kW}\end{array}$ \\
\hline September 2014 & 152.0 & 84.0 & May 2015 & 208.0 & 112.8 \\
\hline October 2014 & 279.0 & 85.5 & June 2015 & 203.0 & 123.4 \\
\hline November 2014 & 247.0 & 87.3 & July 2015 & 157.0 & 83.7 \\
\hline December 2014 & 329.0 & 123.8 & August 2015 & 156.0 & 85.0 \\
\hline January 2015 & 343.0 & 122.4 & \multicolumn{3}{|l}{} \\
\hline February 2015 & 375.0 & 120.6 & $\begin{array}{c}\text { Entire heating } \\
\text { season }\end{array}$ & 375.0 & 119.1 \\
\hline March 2015 & 319.0 & 153.9 & Summer season & 203.0 & 95.3 \\
\hline April 2015 & 341.0 & 149.7 & Year & 375.0 & 118.8 \\
\hline
\end{tabular}

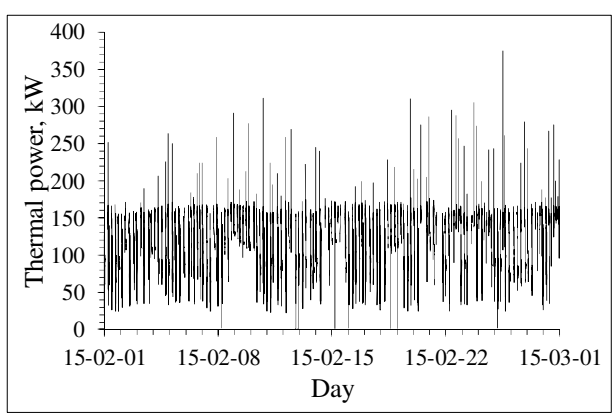

Fig. 5. Results of the gas-fired boiler (KG) thermalpower measurements in February 2015

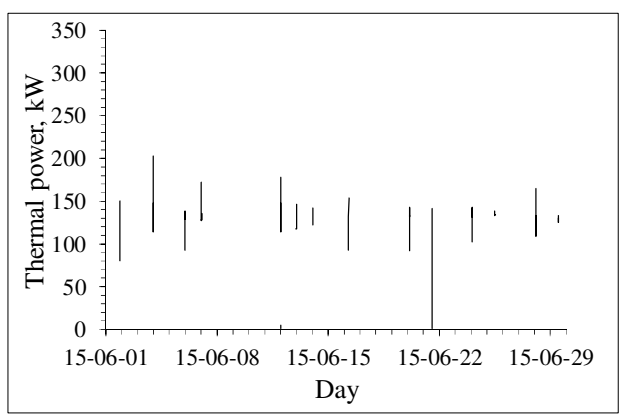

Fig. 6. Results of the gas-fired boiler (KG) thermalpower measurements in June 2015

\section{Working time characteristics}

The activation of each energy-generating device is related to transferring thermal energy to the buffer tank. An exception is the activation of the gas-fired boiler burner where thermal energy cannot be transferred unless the boiler circulation pump is activated (Fig. 1, where the pump is marked as P2). The longest working time is found for the brine-to-water heat pump PC1 - 1875.1 hours, 1103.6 of which was operation at the first degree of the power output and 771.5 hours - at the second. The next longest working times are for the solar collectors -1341.4 hours, the gas-fired boiler $(\mathrm{KG})$ - 1085.6 and the air-to-water heat pump 
PC2 - 321.1 hours. As presented in Table 2, the annual working time of an individual device does not depend on the device installed power. The gas-fired boiler (KG) overall working time during the heating season $-1072.2 \mathrm{~h}$ - is almost 75 times longer than the working time measured in the summer season $-14.4 \mathrm{~h}$. The average duration of the gas-fired boiler operation cycle in the entire year is $0.8 \mathrm{~h}$.

The shortest $-0.1 \mathrm{~h}$ - was recorded in June and July 2015, and the longest $-1.5 \mathrm{~h}-$ in January 2015. 1411 starts were measured when the boiler joined in to operate within the heating system. The calculation results indicate that during the year the boiler operated using the phenomenon of water vapor condensation in flue gases for 283.5 hours, which makes up $26.1 \%$ of the entire operation during the year. The boiler total working time per month ranged from 3.1 to 226.3 hours. Table 2 below presents the calculation results obtained based on the working time of the gas-fired boiler.

Table 2. Results of measurements and calculations of the gas-fired boiler (KG) working time

\begin{tabular}{|c|c|c|c|c|c|}
\hline \multirow[t]{2}{*}{$\begin{array}{c}\text { Analysis } \\
\text { period }\end{array}$} & \multirow{2}{*}{$\begin{array}{c}\text { Number of } \\
\text { boiler starts } \\
- \\
\end{array}$} & \multirow{2}{*}{$\begin{array}{c}\begin{array}{c}\text { Total working } \\
\text { time } \\
\text { (number of boiler } \\
\text { pump starts) }\end{array} \\
H \\
\end{array}$} & \multirow{2}{*}{$\begin{array}{c}\text { The average } \\
\text { length of } \\
\text { boiler } \\
\text { operation }\end{array}$} & \multicolumn{2}{|c|}{$\begin{array}{l}\text { Operating time of the boiler with } \\
\text { a percentage share of water } \\
\text { steam condensation }\end{array}$} \\
\hline & & & & $H$ & $\%$ \\
\hline Sept 2014 & 18 & 3.2 & 0.2 & 1.8 & 54.4 \\
\hline Oct 2014 & 130 & 83.9 & 0.6 & 15.9 & 19.0 \\
\hline Nov 2014 & 288 & 157.8 & 0.5 & 46.8 & 29.6 \\
\hline Dec 2014 & 164 & 203.2 & 1.2 & 22.9 & 11.3 \\
\hline Jan 2015 & 150 & 226.3 & 1.5 & 104.1 & 46.0 \\
\hline Feb 2015 & 137 & 195.7 & 1.4 & 21.1 & 10.8 \\
\hline Mar 2015 & 193 & 107.6 & 0.6 & 58.3 & 54.2 \\
\hline Apr 2015 & 171 & 79.6 & 0.5 & 44.2 & 55.6 \\
\hline May 2015 & 65 & 16.1 & 0.2 & 7.8 & 48.6 \\
\hline Jun 2015 & 40 & 3.1 & 0.1 & 2.2 & 72.8 \\
\hline Jul 2015 & 39 & 4.7 & 0.1 & 2.2 & 47.0 \\
\hline Aug 2015 & 16 & 4.3 & 0.3 & 2.0 & 45.9 \\
\hline $\begin{array}{c}\text { Heating } \\
\text { season }\end{array}$ & 1296 & 1071.2 & 0.8 & 233.6 & 21.8 \\
\hline $\begin{array}{c}\text { Summer } \\
\text { season }\end{array}$ & 115 & 14.4 & 0.1 & 49.9 & - \\
\hline $\begin{array}{c}\text { One } \\
\text { year period }\end{array}$ & 1411 & 1085.6 & 0.8 & 283.5 & 26.1 \\
\hline
\end{tabular}

The shortest $-0.1 \mathrm{~h}-$ was recorded in June and July 2015 , and the longest $-1.5 \mathrm{~h}-$ in January 2015. 1411 starts were measured when the boiler joined in to operate within the heating system. The calculation results indicate that during the year the boiler operated using the phenomenon of water vapor condensation in flue gases for 283.5 hours, which makes up $26.1 \%$ of the entire operation during the year. The boiler total working time per month ranged from 3.1 to 226.3 hours.

\section{Heat generation efficiency characteristics}

The efficiency of thermal energy generation by the gas-fired boiler (KG) during the measuring period was calculated as the ratio between the thermal energy measured by heat meter LC1 and the measured amount of natural gas-fired in the boiler multiplied by the gas lower heating value: 


$$
\varepsilon_{W Y, K G}=\frac{E_{L C 1}}{V_{K G} \cdot W_{d_{g}}}
$$

where :

$E_{L C l} \quad-\quad$ thermal energy generated by the gas-fired boiler $(\mathrm{KG})$ and recorded by heat meter LC1 in GJ,

$V_{K G} \quad-\quad$ the boiler recorded natural gas consumption - gas meter (GM) reading reduced by gas consumption for cooking in $\mathrm{m}^{3}$,

$W_{d_{g}} \quad-\quad$ a lower heating value the gas fuel in $\mathrm{GJ} / \mathrm{m}^{3}$.

Based on the measuring data obtained in the measuring year under analysis, the heat generation efficiency calculated for the gas-fired boiler $(\mathrm{KG})$ is $\varepsilon_{\mathrm{WY}, \mathrm{KG}}=0.96$ per year, for the heating season $-\varepsilon_{\mathrm{WY}, \mathrm{KG}}=0.96$ and for the summer season $-\varepsilon_{\mathrm{WY}, \mathrm{KG}}=0.60$. The arithmetic mean calculated from the monthly efficiency values is 0.82 , and is therefore not comparable to the annual results of calculation of generation efficiency $-\varepsilon_{\mathrm{WY}, \mathrm{KG}}$. An analysis of the measurement data indicates that the monthly heat generation efficiency was the highest in December $2014-\varepsilon_{\mathrm{WY}, \mathrm{KG}}=0.99$. The lowest efficiency value was found for the device in September $2015-\varepsilon_{\mathrm{WY}, \mathrm{KG}}=0.49$. A rising trend can be observed for the changes in efficiency from October to April. The boiler momentary efficiency for the burner minimum and maximum power was $98.4 \%$ and $97.6 \%$, respectively.

\section{Conclusions}

Based on the measurements and calculations carried out, the following conclusions can be drown:

- The amount of thermal energy produced by a given energy-generating device is not proportional to its installed power but depends substantially on the device working time within the system. The installed power of the gas-fired boiler KG is $186 \mathrm{~kW}$, but its percentage share of the annual thermal energy production is $51.11 \%$. For the $81.1 \mathrm{~kW}$ heat pump PC1, the percentage share of the overall annual thermal energy generation is $43.02 \%$. These results are also confirmed by the simulation of the hydronic system operation using the Polysun program.

- Energy-generating devices operate cyclically. For this reason, the recorded values of power generated due to the operation of the devices varied in a wide range, including values exceeding the device rated power. This phenomenon is related to the fact that the system is considerably cooled at the start-up of the energy-generating device.

- The gas-fired boiler (KG) operation characteristics in the winter and the summer season differ substantially. In the winter (heating) season, the boiler is activated fast and dynamically with hot water transferred into the buffer system. In the summer season, long periods occur, even up to a few days, when water remains cool in the boiler water region.

- The heat generation efficiency of the gas-fired boiler (KG) averaged per year is $\varepsilon_{\mathrm{WY}, \mathrm{KG}}=0.96$. In the heating season, the efficiency value is almost equal to the annual average, but it drops significantly in the summer season to $\varepsilon_{\mathrm{WY}, \mathrm{KG}}=0.60$.

- In a hybrid system, heat generation efficiency is strongly dependent on specific system parameters. Such relations should be identified, e.g., by computer simulations in advance and can be a starting point for design and optimization of complex hybrid systems in which conventional and renewable heat sources are used. 


\section{References}

1. Ramos A., Chatzopoulou M. A., Guarracino I., Freeman J., Markides Ch. N., Hybrid photovoltaic-thermal solar systems for combined heating, cooling and power provision in the urban environment, Energy Conversion, and Management, 150, pp. 838-850, (2017)

2. Heinen S., Burke D., O’Malley M., Electricity, gas, heat integration via residential hybrid heating technologies - An investment model assessment, Energy, 109, pp. 906-919, (2016)

3. Wei K., Li W., Li J., Wang Y., Zhang L., Study on a design method for hybrid ground heat exchangers of ground-coupled heat pump system, Int. J. of Refrigeration, 76, pp. 394-405, (2017)

4. Li S., Li S., Zhang X. Comparison analysis of different refrigerants in solar-air hybrid heat source heat pump water heater, Int. J. of Refrigeration, 57, pp. 138-146, (2015)

5. Vasiliev L.L., Kakaç S. Eds. Heat Pipes and Solid Sorption Transformations: Fundamentals and Practical Applications, CRC Press, Taylor \& Francis Group, Boca Raton, Florida, USA, (2013) 